\title{
腎外傷に括ける手術適応の検討
}

$\begin{array}{ccccc} & \text { 岡 } & \text { 田 } & \text { 清 } & \text { 己 } \\ & \text { 遠 } & \text { 藤 } & \text { 克 } & \text { 則 } \\ & \text { 野 } & \text { 垣 } & \text { 譲 } & \text { 二 } \\ & \text { 川 } & \text { 田 } & & \text { 望 } \\ \text { 日本大学医学部泌尿器科学教室 } & \text { 吉 } & \text { 田 } & \text { 利 } & \text { 夫 } \\ (\text { (主任:岸本 孝教授) } & \text { 佐 } & \text { 藤 } & \text { 安 } & \text { 男 } \\ & \text { 森 } & \text { 田 } & \text { 博 } & \text { 人 } \\ & \text { 能 } & \text { 谷 } & \text { 振 } & \text { 作 } \\ & \text { 北 } & \text { 島 } & \text { 清 } & \text { 彰 } \\ & \text { 岸 } & \text { 本 } & & \text { 孝 } \\ & & & & \end{array}$

\section{CLINICAL STUDY OF THE SURGICAL APPLICATION FOR RENAL TRAUMA}

\author{
Kiyoki Okada, Katsunori Endo, Joji Nogaki, Nozomu Kawata, Toshio Yoshida, \\ Yasuo Satoh, Hirohito Morita, Shinsaku Kumagai, Kiyoaki Kitajima \\ and Takashi Kishimoto \\ Department of Urology, Nihon University School of Medicine \\ (Director: Prof. T. Kishimoto)
}

One hundred and twenty-two cases with renal (blunt) trauma were reviewed and analyzed in order to obtain the best clinical guideline in terms of conservative or operative treatment. The cases were classified as renal contusion, slight renal laceration, severe renal laceration, renal rupture and renal pedicle injury by the clinical findings and the image diagnosis. The preoperative classification and the postoperative one including the findings of the operation agreed with 30 of 41 cases $(73.2 \%)$.

According to the present investigation, our current therapeutic policy has been summarized as follows. Renal contusion is managed expectantly. Slight renal laceration is also conservatively observed. However, operation should be taken into consideration in patients with severe renal laceration, because most cases after conservative treatment were obliged to undergo nephrectomy once in a while. The immediate surgery would be the best management for renal rupture as well as renal pedicle injury.

Of special emphasis is that surgical intervention should be employed in cases of sever renal laceration, after an accurate staging is obtained with the aid of image diagnosis.

要旨：過去12年半にわたり経験した腎外傷 (皮下損傷) 122 例を集計し, その即時手術の適応に関し検討 を加えた。外傷度分類は腎挫傷, 軽度腎裂傷, 高度腎裂傷, 腎断裂傷, 腎茎部損傷に分類した。これは 術前の臨床症状と画像診断にて分類した群と, 術中の手術所見を合わせて分類した群とを比較すると約 4 分の 1 は誤謬を生じていた。今後画像診断学の進歩により診断率は高まるものと期待している.

今回の臨床的検討より次のことが要約される，腎挫傷は待期療法が選択される，軽度腎裂傷も手術の 必要はなく, 待期療法で観察することが望ましい, 高度腎裂傷の場合, 待期療法では腎感染が増悪し, 腎障害が進行し, 手術の時期を逸してしまらことがある. そのため, 即時手術が必要である. 腎断裂傷, 腎茎部損傷は待期的に観察せずに即時手術を行らべきである，特に重要なことは，高度腎裂傷との診断 が得られたら，即時手術を行らことである。 


\section{I. 緒 言}

腎外傷（以下，すべて皮下損傷）を治療するにあた り重要なことは, 外傷程度 (外傷度分類)をすみやか に把握し，治療方針を決定することである，腎外傷の らちでも軽症であれば待期療法を行らこと, 重症であ れば即時手術療法を行らことは異論の余地はない。乙 かし，この中間にあたる症例をどのように治療するか が従来より論争の焦点であった ${ }^{11}$.すなわち, 待期療法 を行らべきと考学る根拠は, 待期療法でも腎は自然に 回復するといらこと, 手術を行うと腎摘になることが 多いといらこと, 待期療法の合併症はまれであること, に起因している2) 4). 一方, 積極的に手術をすすめる理 由として, 待期療法を行うとその後に現れる合併症の ため腎摘になることが多いこと, 手術術式の進歩によ り腎を温存することができるようになった，という意 見である ${ }^{5) 77}$. 今回, この問題の解決の一助とするた め, われわれが経験した腎外傷をまとめ, retrospective にみて, 腎外傷の手術療法の適応となる ものは何であるかを検討してみたい。

\section{II. 対象症例の背景因子}

1973年 1 月より 1985年 6 月までの 12 年 6 カ月間に日 本大学医学部泌尿器科学教室拈よびその関連病院に拉 いて経験した122例を対象とした。性別では男性101例 (82.8\%)，女性 21 例（17.2\%）である。年齢は 4 歳か ら76歳までにわたり，10歳台39例(32.0\%)，20歳台25 例 (20.5\%) と若年層に多く認められた（表 1 ).

原因をみると，打撲が最も多く49例（37.7\%）であ り，そのなかにはスポーッ，喧嘩などが含まれている。 次に交通事故が33例（27.0\%）であり，多くはオート バイの事故である.小児に多いのは自転車で転ぶ事故, 中年の女性では自転車にぶつかる事故がめだつ, 次が 労災以外の転落事故で，22例（18.0\%）であった。労

表 1 年齢, 性別分布

\begin{tabular}{c|c|c|l}
\hline \multicolumn{1}{c|}{ 年齡 } & 男性 & 女性 & \multicolumn{1}{|c}{ 計 } \\
\hline $0-9$ & 9 & 6 & 15 \\
$10-19$ & 34 & 5 & $39(32.0 \%)$ \\
$20-29$ & 24 & 1 & $25(20.5 \%)$ \\
$30-39$ & 8 & 4 & 12 \\
$40-49$ & 12 & 2 & 14 \\
$50-59$ & 10 & 1 & 11 \\
$60-69$ & 4 & 1 & 5 \\
$70-$ & 0 & 1 & 1 \\
\hline 計 & 101 & 21 & 122 \\
\hline
\end{tabular}

災事故は18例（14.8\%）であり，転落が多いが，物が 上から落ちて側背部をらつ事故も認められた。

外傷の損傷側としては, 左腎56例(45.9\%), 右腎62 例 $(50.8 \%)$, 両側腎 1 例, 不明 3 例となっている。

合併する外傷についてみると，122例のうち，96例 （8.7\%）が単独腎外傷であったが，26例には合併損傷 があり, 頭部外傷 8 例, 胸部外傷 7 例, 腹腔内臟器損 傷 8 例, 骨盤骨折 3 例, 四肢骨折 6 例, 他 5 例であっ た。

外傷と関達する先駆腎病変の有無に関しては, 122例 中 7 例 $(5.7 \%)$ に存在した。 その内訳は水腎症 4 例, 襄胞腎 2 例, 腎囊腫 1 例である。

$$
\text { III. 結果 }
$$

\section{1. 腎外傷度分類}

第72回日本泌尿器科学会総会のミニシンポジュウム に和ける分類は8)腎挫傷, 腎裂傷, 腎断裂傷, 腎茎部損 傷の 4 群分類である.今回はこれの変法を用いた。 ま ず，初診時に臨床所見および画像により臨床的分類を 行ったので, その診断根拠，基準につき記す。

第 1 群, 腎挫傷: 自覚症状は初診時, 強い側腹部痛, 圧痛があり，血尿も明らかである。しかし，IVPでは 患腎の排泄はやや不良となることがあるが，一般には 造影剤の溢流はみられない,ただし，CT では変化のみ られることがある（図 1).

第 2 群, 腎裂傷 : 局所所見は強く, defense も著明と なり, 腹部腫瘤を触れることがある。レ線上, 腎周囲 には血腫があり, また, 造影剤の溢流を認める。しか し, この群は損傷程度にかなりの幅があり, 臨床経過

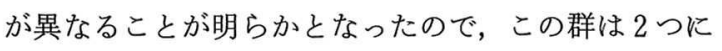
分けるべきと考学た、第 1 組は腎周囲に血腫形成, 造

図 1 左腎挫傷. CT にて腎実質内に溢流が認められ る.

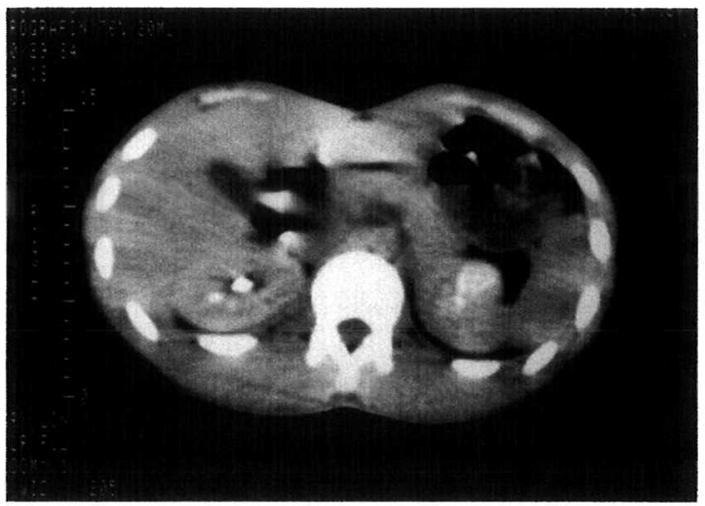


影剤の漏れは存在しているが，腎の変形，変位は軽度 である場合であり，これを軽度腎裂傷とした（図 2 ）。 第 2 組は腎の変形, 変位, 腎孟の変化が加わり, 血腫 形成，造影剤の漏れも著明で，これを高度腎裂傷とし た（図 3 ).

第 3 群，腎断裂傷：局所所見は明らかであり，しば しば vital signの低下をみることがある。レ線上，腎 の変形，拡大は著しいＩVP で不明なとさ，アンギオ にて診断されることもある(図 4).

第 4 群，腎菱部損傷：血尿はむしろ少なく, vital signの低下がみられ，腹部腫瘤と触知する，貧血が進 行し，血圧の低下が持続する。レ線上，腎からの造影 剂の排泄はみられない。アンギオにて腎動脈の途絶が 認められる(図 5 )。

以上の臨床所見, 画像診断より 122 例を臨床的外傷度 分類を打こなってみると，第 1 群，腎挫傷67例

図2 右軽度腎裂傷。CTにて腎周囲の血腫が明らか である。

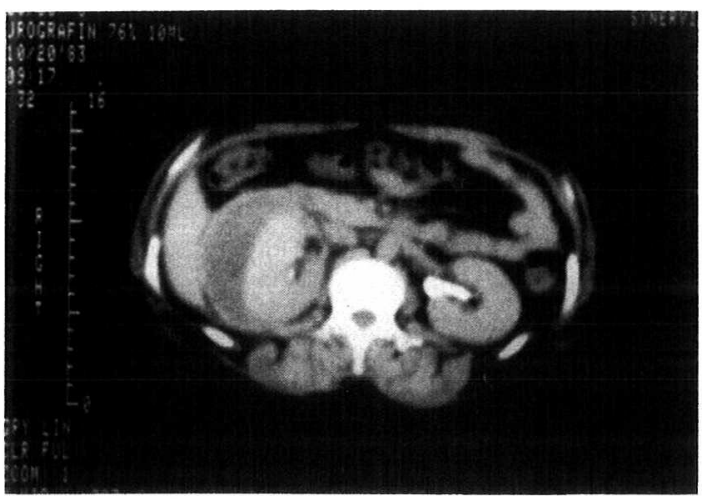

図 3 右高度腎裂傷。腎孟より腎被膜にかけて腎裂傷 があり, 腎の変形が著明。

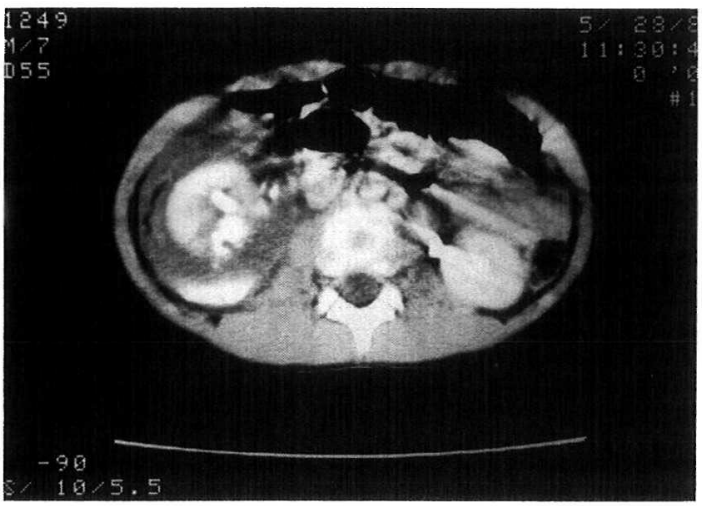

図 4 右腎断裂傷.アンギオにても腎の断裂が明らか である。

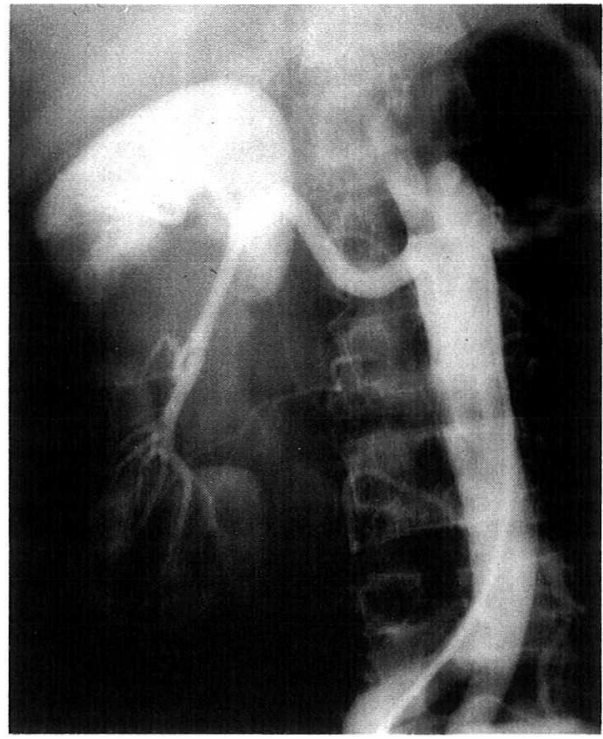

図 5 左腎茎部損傷、アンギオにて左腎動脈の途絶が みられる。

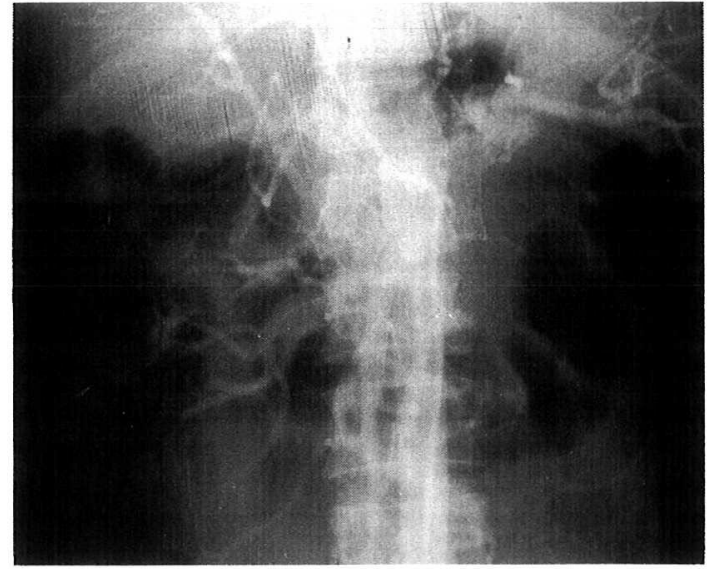

(54.9\%)，第 2 群腎裂傷38例であり，そのうちで軽度 腎裂傷は15例（12.3\%)，高度腎裂傷は23例（18.9\%） である。第 3 群腎断裂傷16例(13.1\%)，第 4 群腎茎部 損傷 1 例 $(0.8 \%)$ であった。

2. 臨床的外傷度分類の正確度

以上に示した臨床的外傷度分類がどの程度正確であ るかを手術療法を行った41例を対象として術前，術後 の外傷度を分類し，その正確度を算出した。41例中正 しかったのは 30 例， $73.2 \%$ であり，約 4 分の 1 は実際 とは異なることが示された(表 2 )。腎挫傷と診断した 
表 2 術前, 術後の外傷度分類

\begin{tabular}{c|c|c|c|c|c}
\hline 術前 & 軽度裂傷 & 高度裂傷 & 断 裂 傷 & 腎茎損傷 & 計 \\
\hline 軽度裂傷 & 2 & 4 & 0 & 0 & 6 \\
高度裂傷 & 2 & 15 & 2 & 0 & 19 \\
断 裂 傷 & 0 & 0 & 12 & 0 & 12 \\
腎茎損傷 & 0 & 1 & 2 & 1 & 4 \\
\hline 計 & 4 & 20 & 16 & 1 & 41 \\
\hline
\end{tabular}

表 3 治療法

\begin{tabular}{r|c|c|c|c|c|c}
\hline & 挫傷 & 軽度裂傷 & 高度裂傷 & 断裂傷 & 腎茎損傷 & 計 \\
\hline 待期療法 & 67 & 11 & 3 & 0 & 0 & 81 \\
\hline 即時手術 & & & & & & \\
腎摘 & 0 & 0 & 3 & 5 & 2 & 10 \\
部分切除 & 0 & 0 & 1 & 3 & 0 & 4 \\
縫合術 & 0 & 1 & 7 & 0 & 0 & 8 \\
ドレナーシ & 0 & 3 & 1 & 0 & 0 & 4 \\
\hline 待期後手術 & & & & & & \\
腎摘 & 0 & 1 & 6 & 4 & 2 & 13 \\
ドレナーシ & 0 & 1 & 1 & 0 & 0 & 2 \\
\hline 計 & 67 & 17 & 22 & 12 & 4 & 122 \\
\hline
\end{tabular}

例では 1 例も手術を行っていないので，その正確度は 不明であるが, 臨床経過からみて正しかったと考える。 腎裂傷は比較的正確であったが，最も診断困難であっ たのが腎茎部損傷である。これは少しでも血管に損傷 があるものは全部これに分類したためであるが，腎裂 傷，腎断裂傷と合併した症例があり，術前診断が不可 能であった。術前高度腎裂傷と診断し, 術後, 腎茎部 損傷と診断した例は摘出標本にて腎動脈の内膜損傷が あった例である。

以上の手術所見を加味し，最終的に外傷度分類を拀 こなってみると，腎挫傷 67 例 $(54.9 \%)$, 軽度腎裂傷 17 例 $(13.9 \%)$ ，高度腎裂傷22例 (18.0\%)，腎断裂傷12 例 $(9.8 \%)$, 腎茎部損傷 4 例（3.3\%）となり，以下, この分類の数字で治療法を検討する.

\section{3. 治療法（表 3)}

ここで即時手術とは受傷後48時間以内に行った場合 であり，必ずしも緊急手術を意味するものではない。 これは即時手術を行うといら方針の症例をみると, 結 果的には48時間以内までの症例が含まれていたためで ある. 待期療法後手術療法例とは48時間以上経過して から手術を行った例であり，多くは 7 日以上経過した のち, 手術を行った症例で, 最長 41 日である。腎挫傷
67例, 全例待期的に治療し, 後療法をつけ加えたのは 1 例もない，軽度腎裂傷17例のうち無処置は11例であ る. 1 例は即時手術にて腎縫合術を行い腎を温存する ことができた。ドレナージのみで終ったのは即時，待 期療法をあわせ 4 例であった。腎摘となったのは 1 例 のみである。これは先天性水腎症があり，それに腎感 染が加わったために 7 日後に腎を摘出している，高度 腎裂傷22例中, 待期療法を行ったのは 3 例のみであっ た．19例（86\%）には何らかの手術が必要であった。 特に, 即時手術の場合は 12 例中 9 例（75\%）は腎を温 存することができた。 その内訳として, 腎縫合術 7 例, 腎部分切除術 1 例，ドレナージ 1 例となっている。し かし，待期療法を行った場合， 7 例のらち 6 例(86\%) は腎摘となっている，その理由として，先天性水腎症 2 例, 腎感染 3 例, 血尿高度で貧血となった 1 例であ る.腎断裂傷は 12 例であり,すべて手術療法を括こなっ ている，即時手術を行った 8 例中 3 例は腎を温存する ことができたが，待期療法後に手術を拉こなった場合 はすべて腎摘となった。腎茎部損傷の 4 例はいずれの 時期でも全例腎摘であった。即時手術を行った 2 例は 腎断裂傷を伴った腎静脈の損傷であった。待期療法後， 腎摘となった例では 7 日，20日後に手術した症例で, いずれも腎動脈内膜損傷であり，血栓形成を伴ってい た.

\section{IV. 考 案}

腹部に外傷を受けたとき，腎臓単独で外傷を受ける ことは少なく, 他の腹腔内蔵器外傷を併発することが 多(7)99. 合併損傷の有無は腎外傷の治療を行ら上で重 要である. 合併症の如何によっては救命処置が優先さ れ，腎外傷の治療は後回しにされたり，または即，腎 摘となる場合もある。自験例では合併損傷のない腎外 傷単独が122例中 96 例, 約 $80 \%$ であった。このことは腎 外傷の病態, 治療法を検討するには理想的な背景因子 であると考える。

腎外傷の治療法で問題となることは，待期的にする か，手術するか，するのであればいつ手術を行らべき かを決定することである. vital sign に変化があり, 腎 茎部損傷が疑われれば緊急手術が優先される。しかし， それ以外のときは，外傷度分類を行ってから治療方針 が決定されよう。腎外傷は種々の分類がなされている $か^{2}{ }^{210111)}$ ，現在 4 期，すなわち，腎挫傷，腎裂傷，腎断 裂傷, 腎茎部損傷に分ける方法が一般に受け入れられ ている ${ }^{12)}$.

外傷度分類を早期に正確に分類をすることは決して 
容易ではない. 初期の頃, われわれはIVPを中心に診 断し，アンギオは少数例に施行したにすぎない，今回 の集計は初期の症例も含まれていたため, 分類の精度 は決して高いものではなかった。しかし, 最近は画像 診断法の進歩により非侵襲的に容易にかつ正確な分類 が可能となった ${ }^{13)}$. 腎外傷の治療に関して, 腎挫傷は待 期療法を行らこと,腎茥部損傷は緊急手術を行らこと， これについては意見の一致しているところである。

Ahmed ら ${ }^{14)}$ は腎断裂傷を待期的に治療した12例の 小児例を経験し，腎裂傷とは予後が異なるとのべてい る。また, Jakse ら ${ }^{15}$ は高度腎裂傷と腎断裂傷に対して 小児30例に手術を行っている，それを長期間 follow up した結果を発表し，3 例に高血圧，1例に腎萎縮が みられたが，その他の例では術後合併症は全くなかっ たという。今回の結果から腎断裂傷につき次のように 考える。第 1 は術前腎断裂傷と診断した 16 例のうち 2 例は腎茥部損傷であったこと, 第 2 は待期療法を行っ てもいずれは手術療法に移り, 腎摘となってしまらこ と, 第 3 には即時手術を行えば腎保存も可能であるこ と,の理由から腎断裂傷と診断されればただちに手術 をすべきである。

論争の焦点は腎裂傷の治療法である。腎がかなり破 壊し, 溢流があっても待期的治療をおこならべきと主 張する論文も散見される ${ }^{16)}$.一方, Reid ${ }^{6}$ は17例の高度 腎裂傷（Type 4, complete tear）の小児例のらちで 5 例は症状が安定していたため待期療法にて観察した。

しかし，そのうちの 2 例は水腎症および腎機能低下の ため腎摘をおこない，1例は蓑腫形成のため腎部分切 除術を行ったという.Jakse らの症例15)もかなり高度 腎裂傷が含まれて括り，手術により合併症の併発が避 けられたことを報告し，手術療法の優位性を認めてい る。一般にこの腎裂傷は非常に幅が広く，多くの症例 が混入しているため治療上での混乱がさらに高まって いるのではないかと考学る，そこで，腎裂傷を細分化 する必要もあるが，当然，正確なる画像診断が望まれ る.CTは患者に比較的侵襲を与えることなく，腎損傷 程度を診断するよい手段とい党る。 McAninch ら ${ }^{17)}$ IVP で正常であった 5 例に CT で造影剂の流出を認 め，腎裂傷と診断でさた例を発表している。ささら， CT を用いることにより軽度腎裂傷と高度腎裂傷とを 鑑別することができると述べている.以上のことより，

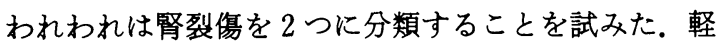
度腎裂傷は17例のらち11例は待期療法で治瘾してお り, 多くの症例は待期的に治療可能であった。一方,
高度腎裂傷では待期療法で治瘾したのは 4 例のみで, あとはいずれかの手術法がとられている，即時手術を 行ったときは腎が温存できた症例は $75 \%$ におよび, 待 期療法の場合は $86 \%$ が腎摘となったことは注目すべき ことである. 待期療法を行うと腎感染が問題であり，

腎摘となることが多いことを強調したい，現在，かな りの高度の裂傷があっても腎茎部の血管を確保すれ ば18)，腎縫合ないしは腎部分切除にて患腎を保存する ことができるようになっている19).このことは高度腎 裂傷と診断されれば即時手術を行った方が腎を温存で きることを示している，腎茎部損傷を手術により腎を 保存することが試みられているが57)，われわれはいま だ経験はない。このようなとさは多くは腎断裂傷，腎 孟尿管損傷のみならず他臓器損傷が合併しているため 腎温存は難しいが，腎温存のために追試すべき手術で ある。

本論の対象は 10 年以上にもわたる症例の集積である ため, 初診時外傷度の診断には不満足なものが含まれ， また時代の变遷により手術術式も改良が加えられてき た。今後，画像診断を十分に利用し，正確な診断を行 いまた新しい手術手技を修得し，外傷腎の温存率を 高めたいと考えている。

\section{V. 結 語}

1. 腎外傷 122 例を集計し，腎外傷の即時手術の適応 に関し検討した。

2. 外傷度分類は腎挫傷, 軽度腎裂傷, 高度腎裂傷, 腎断裂傷，腎茎部損傷に分類すると，術前診断のうち， 約 4 分の 3 が正確な分類であった。術中所見も含め外 傷度分類を行う之, 腎挫傷67例，軽度腎裂傷17例，高 度腎裂傷22例, 腎断裂傷 12 例, 腎茎部損傷 4 例であっ た。

3. 治療法としては, 腎挫傷はすべて待期的に治療 し，治瘾している。軽度腎裂傷は手術を行った症例も あるが，待期療法で軽快している，高度腎裂傷は即時 手術にて腎温存が可能であった。しかし，待期療法例 では後日手術が必要となった例が多く，しかも，大部 分腎摘となった。腎断裂傷，腎茎部損傷例は全例手術 が行われた。即時手術にて患腎が温存できた症例も存 在した.

4. 以上の retrospective の考察により腎裂傷が高 度であれば，即時手術を施行すべきであるとの結論を 得た。

本論文の要旨は第72回日本泌尿器科学会総会にて発表し た。 


\section{文献}

1) Ceccarelli, F.E.: Expectant treatment in the management of blunt renal trauma. In current controversies of urologic management. Scott, R., p. 112, Philadelphia, W.B. Saunders Co., 1972.

2) Sargent, J.C. and Marquardt, C.R.: Renal injuries. J. Urol., 63, 1-8, 1950.

3) Peterson, N.E.: Intermediate-degree blunt renal trauma. J. Trauma, 17, 425-435, 1977.

4) Wein, A.J., Murphy, J.J., Mulholland, S.G., Chait, A.W. and Arger, P.H.: A conservative approach to the management of blunt renal trauma. J. Urol., 117, 425-427, 1977.

5) Carlton, C.E. Jr.: Early operation in the management of blunt renal trauma. In current controversies of urologic management. Scott, R., p. 109, Philadelphia, W.B. Saunders Co., 1972.

6) Reid, I.S. : Renal trauma in children : A tenyear review. Aust. New Jeal. J. Surg., 42, 260-266, 1973.

7) Cass, A.S. and Luxenberg, M.: Conservative or immediate surgical management of blunt renal injuries. J. Urol., 130, 11-16, 1983.

8）岡田清己, 野口幸啓, 野垣譲二, 清滰修二, 北島清 彰, 岸本 孝：腎損傷に対する腎縫合術。手術, 36, 863-866, 1982.

9) Peterson, N.E. and Norton, L.W.: Injuries associated with renal trauma,. J. Urol., 109, 766-768, 1973.

10) Cass, A.S.: Renal trauma during laparotomy for intrabdominal injury. Arch. Surg., 110, 950-953, 1975.
11) Carlton, C.E. Jr.: Injuries of the kidney and ureters. In Campbell's Urology. Campbell, M.F., 4th ed., p. 881, W.B. Saunders Co., Philadelphia, 1978.

12）町田豊平：堅外傷．新臨床泌尿器全書 $6 \mathrm{~B}$, p. 1 , 金原出版, 東京, 1982 .

13) Lang, E.K., Sullivan, J. and Frentz G.: Renal trauma: Radiological studies. Comparison of urography, computed tomography, angiography, and radionuclide studies. Radiology, 154, 1-6, 1985.

14) Ahmed, S. and Morris, L.L.: Renal parenchymal injuries secondary to blunt abdominal trauma in childhood: a 10-year review. Brit. J. Urol., 54, 470-477, 1982.

15) Jakse, G., Putz, A., Gassner, I. and Zechmann, W.: Early surgery in the management of pediatric blunt renal trauma. J. Urol., 131, 920-924, 1984.

16) Evins, S.C., Thomason, B. and Rosenblum, R.: Nonoperative management of severe renal lacerations. J. Urol., 123, 247-249, 1980.

17) McAninch, J.W. and Federle, ;M.P.: Evaluation of renal injuries with computerized tomography. J. Urol., 128, 456-460, 1982.

18) McAninch, J.W. and Carroll, P.R.: Renal trauma : kidney preservation through improved vascular control-a refined approach. J. Trauma, 22, 285-290, 1982.

19）遠藤克則，野垣譹二，熊谷振作，岡田清己，岸本 孝：腎外傷の手術適応とその手術方法。日泌尿会 誌, 75, 1755, 1984.

（1985年 9 月 27 日受付） 